\title{
"Ancient fire temples in the light of the discovery at Mele Hairam ». Iranica Antiqua, vol. XXXIX, (2004), pp. 323-337, 8 fig.
}

\section{Rémy Boucharlat}

\section{(2) OpenEdition}

1 Journals

\section{Édition électronique}

URL : http://journals.openedition.org/abstractairanica/5814

DOI : 10.4000/abstractairanica.5814

ISSN : 1961-960X

\section{Éditeur :}

CNRS (UMR 7528 Mondes iraniens et indiens), Éditions de l'IFRI

\section{Édition imprimée}

Date de publication : 15 mai 2006

ISSN : 0240-8910

\section{Référence électronique}

Rémy Boucharlat, « « Ancient fire temples in the light of the discovery at Mele Hairam ». Iranica Antiqua, vol. XXXIX, (2004), pp. 323-337, 8 fig. », Abstracta Iranica [En ligne], Volume 27 | 2006, document 124, mis en ligne le 02 janvier 2007, consulté le 25 septembre 2020. URL : http:// journals.openedition.org/abstractairanica/5814 ; DOI : https://doi.org/10.4000/abstractairanica.5814

Ce document a été généré automatiquement le 25 septembre 2020.

Tous droits réservés 


\title{
« Ancient fire temples in the light of the discovery at Mele Hairam ". Iranica Antiqua, vol. XXXIX, (2004), pp. 323-337, 8 fig.
}

\author{
Rémy Boucharlat
}

1 Mele Hairam, près de Sarakhs à la frontière irano-turkmène, s'est ajouté à la courte liste des temples du feu de l'époque partho-sasssanide (cf. Abs. Ir. 25, c.r. n os 104 et 105, pour une description des découvertes). Celui-ci n'est pas un chahar taq, comme celui de Takht-i Solaiman ou Tureng Tepe, même si la salle principale suit un plan grossièrement cruciforme, comme à Bandian tout proche. Dans tous les cas cités, l'autel et, pour quelques-uns, l'accumulation de cendres sur l'autel ou à côté ne laisse aucun doute sur la fonction de cette salle. Mele Hairam est aussi un ensemble de salles qui satisfont aux exigences du culte et donne l'occasion à l'A. de revenir sur les interprétations données pour les autres temples fouillés.

\section{INDEX}

Thèmes : 3.2.2. Pré-Achéménides et Achéménides 
AUTEURS

RÉMY BOUCHARLAT

IFRI-CNRS - Téhéran-Lyon 